\title{
Prediction of HIV prevalence until 2022 in Romania and the European Union
}

\author{
Predicţia prevalenţei HIV până în anul 2022 în România şi Uniunea Europeană
}

\author{
Ana Maria Alexandra Stănescu', Ioana Veronica Grăjdeanu', \\ Gabriel Cristian Bejan ${ }^{1}$, Ovidiu Gabriel Bratu ${ }^{1,2,3}$, Andrei Kozma ${ }^{5}$, \\ Ioana Florentina Codreanu' ${ }^{1}$, Camelia Cristina Diaconu ${ }^{1,4}$ \\ ${ }^{1}$ Universitatea de Medicină şi Farmacie „Carol Davila“, Bucureşti, România \\ 2Departamentul Urologie, Spitalul Militar Central Universitar de Urgenţă, Bucureşti, România \\ ${ }^{3}$ Academia Oamenilor de Ştiinţă din România \\ ${ }^{4}$ Spitalul Clinic de Urgenţă, Bucureşti, România \\ 5Departamentul Cercetare în Pediatrie Socială şi Obstetrică, INSMC „Alessandrescu-Russescu“, \\ Bucureşti, România
}

\begin{abstract}
In the last decade, AIDS diagnosis has decreased, most likely through easier access to treatment and faster management of HIV infections. Due to the decrease in the number of AIDS patients, the reduction of deaths and the idea of eradication of AIDS can be considered. For all of this, we need to look at the HIV infection that causes AIDS. HIV infection at European level has been declining in recent years, yet there are still countries that continue to grow. Late diagnosis, pre-exposure prophylaxis and the lack of proper education in preven-tion are still a problem in some European Union countries.
\end{abstract}

Keywords: HIV, prevalence, prediction

REZUMAT
În ultimul deceniu, diagnosticarea cu SIDA a scăzut, cel mai probabil prin accesul mai facil la tratament şi
managementul mai rapid al infectărilor cu HIV. Datorită scăderii numărului bolnavilor cu SIDA, se poate lua
în considerare reducerea deceselor, dar şi ideea eradicării SIDA. Pentru toate acestea, trebuie să analizăm
infecţia cu HIV care determină SIDA. Infectarea cu HIV la nivel european înregistrează un declin în ultimii ani,
cu toate acestea, sunt încă ţări care au în continuare un trend crescător. Diagnosticarea tardivă, profilaxia
preexpunere, dar şi lipsa educaţiei corespunzătoare în ceea ce priveşte prevenţia reprezintă încă o problemă
în unele ţări din Uniunea Europeană.

Cuvinte cheie: HIV, prevalenţă, predicţie

\section{INTRODUCERE}

Virusul imunodeficienței umane (HIV) infectează celulele vitale din sistemul imunitar uman, cum ar fi celulele T helper, macrofagele şi celulele dendritice (1). Se disting două tipuri de HIV: HIV-1, care provine de la cimpanzei, are prevalență la nivel global, cu virulență şi rată de transmitere mare, şi HIV-2, care are prevalența în Vestul Africii, iar virulenţa şi rata de transmitere sunt scăzute $(2,3)$.
La nivel global, HIV a reprezentat şi reprezintă în continuare o provocare din punct de vedere medical, dar şi o povară pentru pacient. Costurile foarte ridicate pentru tratarea acestor pacienți reprezintă în mod cert o povară pentru sistemul sanitar din România.

Deşi greu de obținut, țelul de a eradica HIV poate fi realizat printr-o educație continuă a populației în ceea ce priveşte modalităţile de transmitere. De asemenea, este important să se promoveze şi pova- 
ra pe care o poartă pacientul cu HIV de la infectare până la deces. În ceea ce priveşte persoanele deja infectate cu HIV, trebuie insistat asupra modalităților prin care se poate preveni răspândirea infecției.

O altă problemă o reprezintă afecțiunile asociate HIV. O serie de afectiuni non-infecțioase sunt asociate infecției HIV. Printre acestea se numără: hipertensiune sistemică, efuziune pericardică, cardiomiopatie, hipertensiune pulmonară, astm bronşic, boală pulmonară obstructivă cronică, emfizem, boala intestinală inflamatorie, sindrom metabolic, osteonecroza, osteomalacie şi osteoporoze, dermatită seboreică, xeroză, dermatită atopică şi psoriazis, sarcomul Kaposi $(4,5,6,7)$. Toate acestea şi multe altele pot fi reduse semnificativ o dată cu reducerea numărului infectărilor cu HIV. Costul tratării comorbidităților asociate HIV este o altă problemă semnificativă în țara noastră.

\section{OBIECTIVELE STUDIULUI}

Estimarea prevalenței HIV până în anul 2022 în România.

Estimarea prevalenței HIV până în anul 2022 la nivel european

Beneficiile sau dezavantajele, conform estimării

\section{MATERIAL ŞI METODĂ}

S-a realizat un studiu predictiv, utilizând raportul epidemiologic anual al infectării cu HIV şi SIDA pentru anul 2017 al Centrului European de Prevenire şi Control al Bolilor (8). Acesta cuprinde date statistice din perioada 2013-2017.

În urma analizării datelor, am efectuat predicția pe baza ratei istorice anuale medii de creştere pen- tru a estima numărul cazurilor noi de infecții HIV pentru următorii cinci ani (2018-2022). Predicția s-a realizat ținând cont de trendul ultimilor cinci ani, plecând de la ipoteza că trendul se va păstra în următorii cinci ani. Datele au fost analizate şi prelucrate în Microsoft Excel.

\section{REZULTATELE STUDIULUI}

În prima fază s-a luat în considerare numărul de cazuri noi de infectări cu HIV survenite anual pe teritoriul României începând cu anul 2013 până în anul 2017.

Se poate observa trendul descrescător al ultimilor ani (Fig. 1). În 2013, numărul total de cazuri noi diagnosticate cu HIV a fost de 961 de persoane, în comparație cu anul 2017, care a avut un număr de 661.

Utilizând predicția pe baza ratei istorice anuale medii de creştere, am calculat trendul pentru anii 2018 - 2022 în cazul în care se va menține aceeaşi distribuție anuală ca în perioada 2013-2017 (Fig. 2). Scăderea poate fi considerată semnificativă, ținând cont că în 2013 au fost 961 de cazuri noi de infectări cu HIV, iar în 2022 se poate ajunge numai 416 cazuri noi.

În faza a-II-a, s-au luat în considerare numărul de cazuri identificate cu HIV survenite la nivelul Uniunii Europene în perioada 2013-2017 (Fig. 3).

Aici se evidențiază scăderea apărută în anul 2017, de la 31.935 de cazuri noi în 2016 la 27.055 de cazuri noi în 2017.

La nivelul Uniunii Europene, în ceea ce priveşte infectarea cu HIV, este predominant sexul masculin, cu vârsta cuprinsă între 25 de ani şi 29 de ani.

Calea de transmitere cel mai des întâlnită rămâne contactul sexual între bărbați.

— Număr de persoane infectate cu HIV în România anual

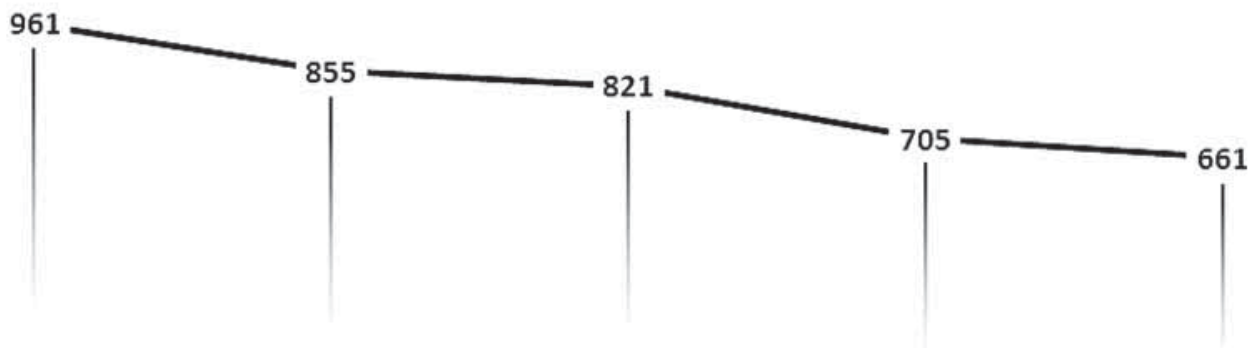




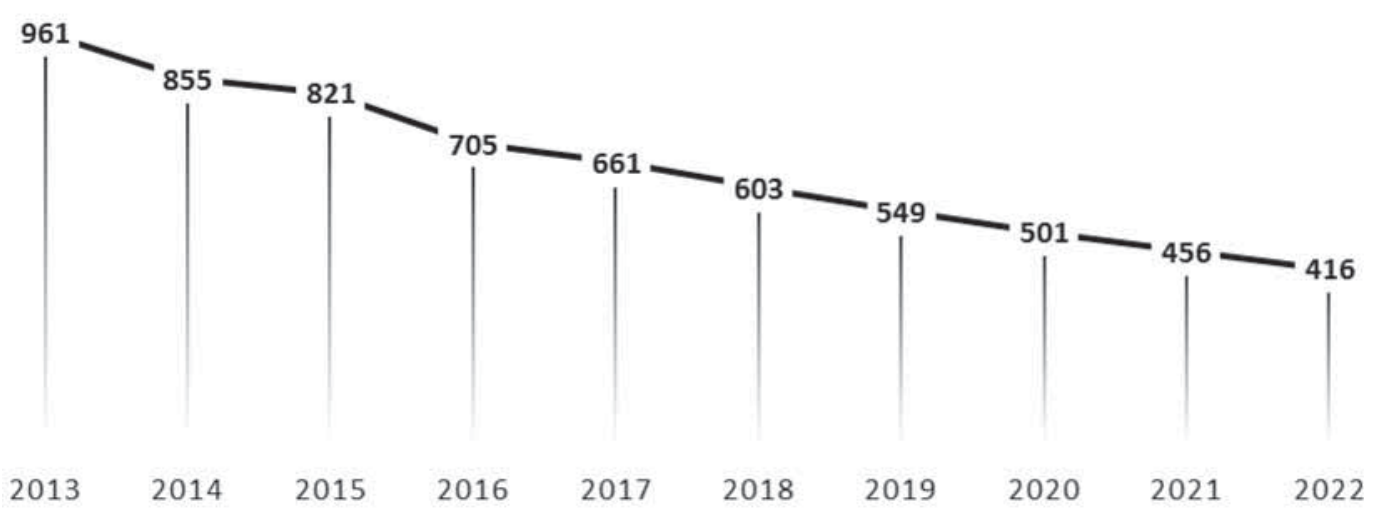

FIGURA 2. Predicția prevalenței cazurilor nou diagnosticate cu HIV în România până în anul 2022
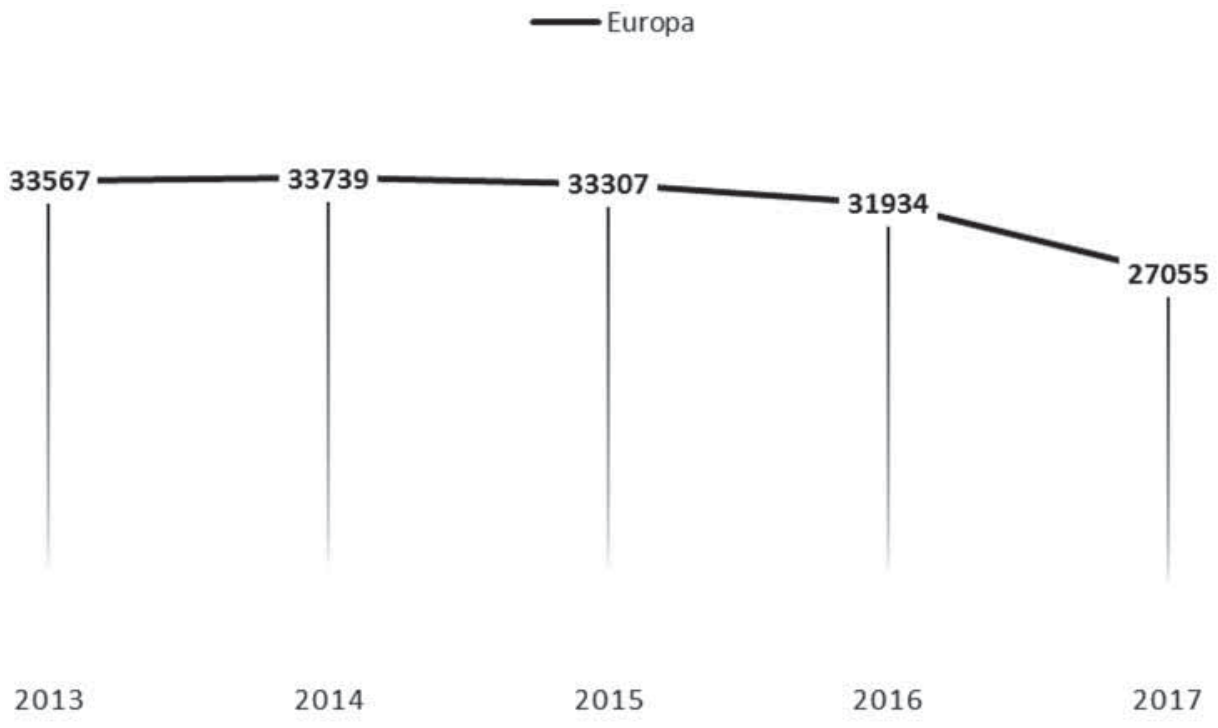

FIGURA 3. Prevalența cazurilor nou diagnosticate cu HIV în Uniunea

Europeană (2013-2017) (8)

Predicția la nivel european are acelaşi trend descrescător, fiind posibil să se ajungă până in anul 2022 in ceea ce priveşte cazurile noi de infectare cu HIV la aproximativ 20.888 de persoane.

\section{DISCUŢII}

Este necesară o mai mare atenție asupra prevenției, mai ales în țările în care numărul de cazuri noi de infectări cu HIV este în creştere.

Țările din Uniunea Europeană care au înregistrat creşteri ale infectărilor noi cu HIV în 2017 comparativ cu 2013 sunt: Bulgaria în 2013 - 200 persoane şi în 2017 - 241 persoane, Croația în 2013
- 85 persoane şi în 2017 - 106 persoane, Cipru în 2013 -54 persoane şi în 2017 - 85 de persoane, Cehia în 2013 - 235 de persoane şi în 2017 - 254 de persoane, Danemarca în 2013 - 233 de persoane şi în 2017 - 242 de persoane, Islanda în 2013 - 11 persoane şi în 2017 - 24 de persoane, Irlanda în 2013 - 342 de persoane şi în 2017 - 483 de persoane, Letonia în 2013 - 340 de persoane şi în 2017 371 de persoane, Lituania în 2013 - 177 de persoane şi în 2017 -263 de persoane, Polonia în 2013 - 1098 de persoane şi în 2017 - 1.325 de persoane (8).

O altă problemă importantă este reprezentată de momentul diagnosticării infecției cu HIV. Se esti- 


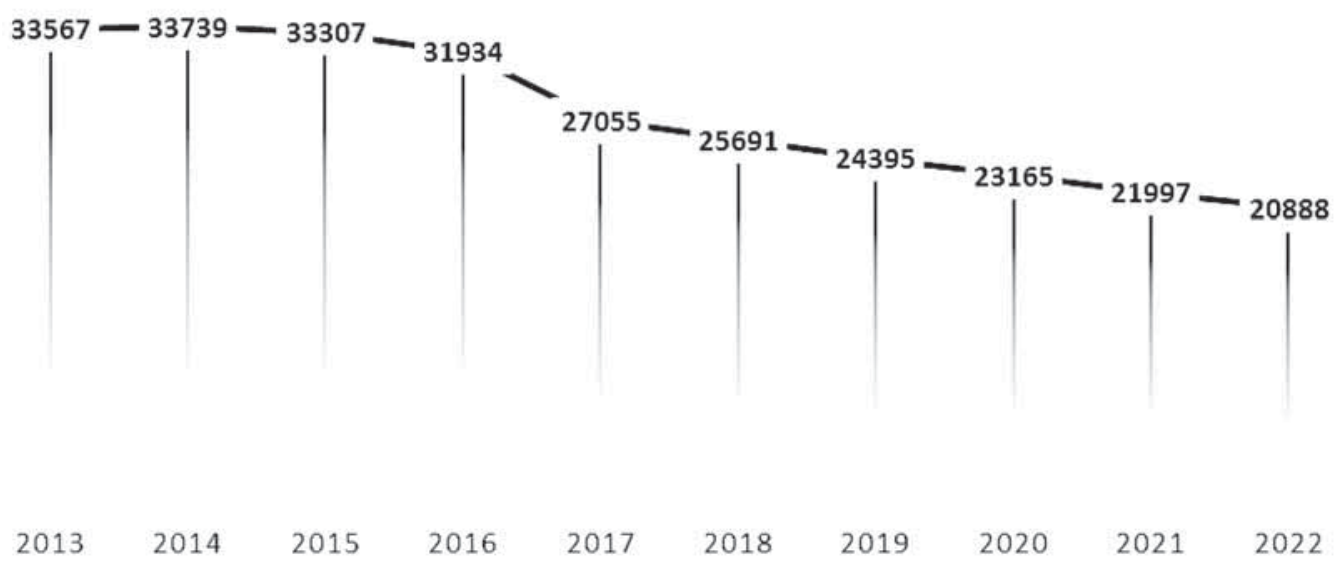

FIGURA 4. Predicția prevalenței cazurilor nou diagnosticate cu HIV în Uniunea Europeană până în anul 2022

mează că între 6\% şi 32\% din populația europeană este purtătoare fără a fi diagnosticată (9). La nivelul Uniunii Europene, media de diagnosticare este de trei ani de la infectare (10). Diagnosticul cu SIDA a fost urmat diagnosticului HIV în maximum 3 luni în $89 \%$ dintre cazuri (8). Se remarcă faptul că diagnosticarea HIV este în general tardivă, făcând posibilă apariția mai multor cazuri de SIDA. Un diagnostic precoce înseamnă acces precoce la tratament, ceea ce duce în general la un prognostic mai bun pentru pacient.

Afecțiunile neurocognitive asociate cu HIV ce au ca principali factori de risc asociați CD4 + scăzut; vârsta > 50 de ani; virusul hepatitei $C$; diabetul sau rezistența la insulină; boala cardiovasculară; nivelul de educație inferior (11) tind să fie mai frecvente în cazurile diagnosticării tardive.

$\mathrm{O}$ altă metodă de a minimaliza infectarea cu HIV este profilaxia preexpunere, care se indică pentru persoanele cu HIV-negativ, dar care au risc crescut de infectare HIV.

Terapiile moderne antiretrovirale pot suprima replicarea virusului HIV, îmbunătăţind sănătatea individului, dar şi reducând posibilitatea transmiterii. Dezavantajul acestor terapii îl reprezintă costurile ridicate, efectele adverse, dar şi perioada nedeterminată de tratament. Noi terapii sunt necesare pentru managementul acestei afecțiuni, în special un tratament curativ. Un studiu a arătat că transplantul de celule stem hematopoietice ar putea fi viitorul tratament curativ al HIV; cu toate acestea, transplantul a fost efectuat unei singure persoane (12).

În ceea ce priveşte confidenţialitatea pacienților cu HIV, dar şi măsurile de prevenire a răspândirii maladiei SIDA, s-au luat măsuri legale atât la nivel european, cât şi la nivelul fiecărei țări în parte. În România, criteriul legal care deserveşte aceşti pacienți se găseşte în Legea nr. 584 din 29 octombrie 2002 privind măsurile de prevenire a răspândirii maladiei SIDA în România şi de protecție a persoanelor infectate cu HIV sau bolnave de SIDA (13).

\section{Concluzii}

Datorită trendului descrescător al infectărilor cu HIV din ultimii ani şi în condițiile menținerii aceluiaşi trend, se poate reduce în viitor numărul înbolnăvirilor, ceea ce va duce şi la scăderea ratei de deces. Chiar mai mult, prin continuarea prevenției, în special la persoanele active sexual, există posibilitatea de a se atinge țelul de eradicare a infectărilor cu HIV pe teritoriul României. Datorită accesului facil de deplasare a persoanelor în spațiul european, pentru România este important de menținut trendul descrescător actual al infectărilor cu HIV din Uniunea Europeană.

\section{Mențiune}

Toți autorii au contribuție egală la realizarea acestui articol. 


\section{BIBLIOGRAFIE}

1. Cunningham AL, Donaghy $\mathrm{H}, \mathrm{Harman} A \mathrm{~N}$ et al. Manipulation of dendritic cell function by viruses. Current Opinion in Microbiology 2019;13(4):524-529

2. Gilbert PB, McKeague IW, Eisen G et al. Comparison of HIV-1 and HIV-2 infectivity from a prospective cohort study in Senegal. Statistics in Medicine 2003; 22(4):573-593

3. Olariu C, Nurciu A, Vasilescu I et al. Afectarea măduvei hematogene la pacienţii cu infecţie HIV. Practica Meicală 2018;13,2(57):156-161.

4. Stanescu A.M.A., Matei A., Grăjdeanu I.V., et al. Sindromul metabolic în raport cu nivelul seric al vitaminei $D$ corelat cu afectarea cutanată. Revista Medicală Română 2017; LXIV(4): 300-304.

5. Stanescu AMA, Diaconu CC, lancu MA et al. Psoriazisul şi bolile cardiovasculare: actualităţi în cercetarea medicală. Revista Medicală Română 2018; LXV(1): 41-44.

6. Diaconu CC, Drăgoi CM, Bratu OG et al. New approaches and perspectives for the pharmacological treatment of arterial hypertension. Farmacia 2018;66(3): 408-415

7. Mani D, Haigentz M, Aboulafia D. Lung cancer in HIV infection. Clin Lung Cancer 2019;13: 6-13
8. European Centre for Disease Prevention and Control. HIV infection and AIDS. In: ECDC. Annual epidemiological report for 2017. Stockholm: ECDC; 2019.

9. Brown AE, Hayes R, Noori T et al. HIV in Europe and Central Asia: Progress in 2018 towards meeting the UNAIDS 90-90-90 targets. Euro Surveill. 2018 Nov 29;23(48).

10. van Sighem A, Pharris A, Quinten C et al. The ECDC HIVIAIDS Surveillance and Dublin Declaration Monitoring Networks. Reduction in undiagnosed HIV infection in the European Union/European Economic Area, 2012 to 2016. Euro Surveill. 2017 No v 30;22(4)

11. A. Penalva de Oliveira. HIV, Journal of the Neurological Sciences 2015; 357(1):e463

12. Hutter G, Nowak D, Mossner M et al. Long term control of HIV by CCR5 Delta32/Delta32 stem cell transplantation. N Engl J Med 2009; 360: 692-698.

13. Legea nr. 584 din 29 octombrie 2002, publicată în Monitorul Oficial nr. 814 din data: $11 / 08 / 2002$ 